\title{
УДК 327 \\ FROM THE SERVICEMEN'S READJUSTMENT ACT OF 1944 TO THE \\ LABOUR MANAGEMENT RELATIONS ACT OF 1947: THE SELECTED PROBLEMS OF US LABOUR MARKET POLICIES
}

МІЖНАРОДНЕ ПРАВО

\author{
Kamil Kowalski \\ University of Lodz, Faculty of Economics and Sociology, \\ 41, Rewolucji 1905 Str., Lodz, Poland, 90-214, tel.: +48 600105 729, \\ e-mail:kamil.kowalski@uni.lodz.pl
}

\begin{abstract}
One the main problem of US during World War II evolved around the question how to make the transition to peace as to rebuild the economy that produced military products, in a peaceful way. It was closely connected with the successful implementation of the demobilization of the 12 million army. The no-strike pledge thanks to which the number of strikes was relatively low during World War II was about to expire. Those two factors: demobilization and the excepted divergence between unions and administration were the major determinants of US labour market policies. The Servicemen's Readjustment Act of 1944 (GI Bill of Rights) was a comprehensive program to aid returning veterans in their speedy readjustment to civilian life. The main body of the article is built around the analysis of the provisions of the Act that relate to the benefits for the former soldiers. The Labour Management Relations Act of 1947 (Taft-Hartley Act) was a Republican initiative motivated by a series of large-scale strikes, fear of communist infiltration of labour unions, and the significant growth in both membership and power of unions. All these factors contributed to an anti-union climate in the United States after World War II As a result the bill was passed, but over Truman`s veto which eventually turned out to be a smart political move.
\end{abstract}

Key words: Labour; reconversion; postwar economy; Truman.

As early as in the middle of the US military struggles, on May 27, 1943 Franklin D. Roosevelt appealed to Congress to help future veterans: «We have taught our youth how to wage war; we must also teach them how to live useful, and happy lives in freedom, justice and decency» [16, p. 451]. In one of his chats by the fireplace (July 28, 1943) he indicated that the returning soldiers should not come to the country consumed by inflation and unemployment and live at the breadline «selling apples on the corner» $[16$, p. 333]. Important were the expectations of the American people, to regulate the influx of millions of potential workers, particularly in the context of recent reminiscence of unemployment in the 1930s. There was widespread concern about the destruction of the effects of the war economic boom by the returning excessive number of «working hands» coupled with the decreasing (which was wrongly predicted) supply of jobs [7, p. 12]. Another challenge facing labour market was the no-strike pledge thanks to which the number of strikes was relatively low during World War II. This agreement was expected to expire after the cessation of hostilities. It was generally believed that public's strong return to consumerism following a period of decreased spending would result in the burst pent-up demand boosted by pay rises. The role of trade unions was expected to be strong again. Those

(C) Kowalski Kamil, 2016 
two factors: demobilization and the excepted divergence between unions and administration were major determinants of US labour market policies while the Servicemen`s Readjustment Act of 1944 and the Labour Management Relations Act of 1947 their leading instruments.

This article describes the circumstances of the adoption of one of these two important American legislation on social and labour issues. In terms of GI Bill of Rights the paper discusses the most important areas of assistance provided for by the Act, the amount and duration of benefits. As far as the Taft-Hartley Act is concerned, the emphasis is put on the genesis of legislation and its political perspective.

The Servicemen`s Readjustment Act of 1944 (PL78-346), commonly known as the GI Bill of Rights, was an attempt of a comprehensive approach to demobilization and as such - was the most expensive and the most ambitious plan to absorb the millions of demobilized soldiers by the booming US economy [19, p. 284]. One of the many intentions guiding the creators of the Act was the will not to repeat errors from the period after World War I, when the US authorities lacked imagination, and veterans were offered $\$ 60$ and a train ticket home. It is important to emphasize that, after 1941 the scale of demobilization was much greater: compared to the Great War the number of Americans participating in hostilities quadrupled (from four to sixteen million). Still on the day of Japan's surrender 12.1 million Americans continued to serve in the armed forces, accounting for $2 / 3$ of men aged 18-34 years. The aforementioned Act was an attempt to solve the expected problems in advance.

The Act provided for the four areas of assistance for returning soldiers: education, loans, benefits and help in finding employment. Of particular importance were the provisions relating to soldiers' education. Generally, the program financed education for no longer than four years. This period was dependent on the number of years of military service on the basis of one year plus the number of years of service. Then the federal budget covered expenses for tuition, books, fees for use of the library, laboratories (and their equipment), health care and other expenses. This pool - not exceeding \$500 a year - did not include the costs of transport and maintenance. There was a separate monthly allowance for living expenses of $\$ 50$ or $\$ 75$. The amount of benefits provided for by the Bill was large enough to cover the entire costs of receiving education. In 1945 annual tuition fee for non-veterans at Harvard was $\$ 400$.

Area of education turned out to be the biggest success of the GI Bill of Rights. In 1940 only $33 \%$ of the 75 million Americans over the age of 25 years had education above the 8th grade. $25 \%$ graduated from high school. Only one in 20 representatives of this age group graduated from a college or university. Only $49 \%$ of seventeenyears-olds held a high school diploma (the war negatively affected this index - in 1946 it fell to $47.4 \%$ ) [15, p. 21]. But already in 1947 approx. 1 million veterans accounted for $49 \%$ of students in American colleges. It is worth noting that these figures were a complete surprise for the ruling. It was expected that after leaving the battlefield veterans would be more likely to abstain from knowledge at the secondary and university level. Meanwhile, until 1956, when the period of application of the Bill expired, up to 7.8 million (more than a half) of the former soldiers, benefited from the support in education $[1$, p. 201] with 2.2 million attending colleges $(97.1 \%$ were 
males), 3.5 million in vocational schools, and 2.2 million benefitting from a variety of vocational courses (of which 700,000 were in agriculture) [4, p. 49]. Taking into account the spouses and children, the number of beneficiaries in this area of aid under the GI Bill exceeded 21 million people (1944 to 1952) at a cost to the budget of $\$ 14.5$ billion US [12, p. 134]. As a result, «for half a decade following the war veterans dominated the nation's campuses by their numbers and their academic superiority over nonveteran classmates» $[13$, p. 596].

While in 1940 the number of Americans who gained university titles was 216,000, in 1950 it was 497,000 people [14, p. 68]. In 1940 only $23 \%$ of soldiers held a high school diploma and $3 \%$ completed college. The Bill translated into education among the soldiers, but significantly affected national statistics. In 1940 a total of 160,000 students graduated from college - in 1950 already 0.5 million. Mass participation in courses and systematic education not only increased the skills, making it easier to find a job, but also evenly distributed over time the influx of millions of veterans into the labour market. Their absorption was therefore not abrupt, but adequate for the purchasing needs of society awakened and delayed in time by the war.

The second area covered by the provisions of the Bill was to facilitate applications for loans for veterans. The availability of loans was subject to conditions similar as with educational support. State aid was limited to loans for the construction of houses, farms, their equipment or businesses (only in the US, not overseas). The repayment period could not exceed 20 years. For loans for the above goals, the US government acted as guarantor to repay half of the capital (but not more than \$2000). If installments were not paid by the borrower, the government could file an appropriate claim against him or her. The new solution worked therefore in three ways: encouraged developers to build, bankers to lend, and the veterans to buy.

In addition, the government also financed the interest for the first year of the guaranteed portion of the loan. There was a condition: the interest rate could not exceed $4 \%$. The biggest advantage for veterans was the possibility of obtaining a higher loan amount or better terms and conditions (due to government's guarantee of the half of repayment). Between 1944 and 1952 the US government guaranteed repayment of 2.4 million loans to build a house for the amount of $\$ 16.5$ billion [21, p. 358].

The GI Bill of Rights made thousands of Americans owners of houses, apartments, and businesses. Before World War II to obtain a loan for the construction or purchase of a home was dependent on the possession of $50 \%$ of own contribution. The GI Bill successfully avoided this pitfall. Nearly 5 million veterans have benefited from this assistance. Every second new house built in the US in the first postwar decade was financed with a loan for veterans [7, p. 99]. The result was not only the dynamic development of suburbs, but also increased demand for cars (most of the new houses arose in the suburbs), household appliances and furniture etc. By the end of 1947 the US government guaranteed more than a million loans for the construction of homes and farms. While in 1944 the construction of 114,000 houses began, six years later, it was already 1.7 million. In total, until 1950 the Veterans Administration of the US government endorsed the construction of over two million homes [4, p. 50]. Nearly 
28 percent of the World War II veterans have used GI financed home loans [3, p. 303]. The new buildings were the driving force for local businesses. They stimulated the growth of cities and through the need to build new streets have changed their topography. New shopping centers emerged, as well as new offices, schools, and churches. The rate of construction of new buildings was spectacular, as if to make up for time lost during the war.

Another provision of the GI Bill introduced unemployment benefits. They could be granted for a maximum of one year and only veterans residing permanently in the United States were eligible. It was allowed to collect benefits with part employment, however, earnings on this account could not exceed $\$ 23$ per week. The weekly benefit amount was $\$ 20$. In the case of part-time work the amount of the benefit was subject to reduction by the surplus of weekly earnings over $\$ 3$. The legislator also stipulated that the collection of benefits for the unemployed within the framework of separate state programs reduced the amount of the benefit provided by the Bill. The length of the benefit period was dependent on the length of army service after September 16, 1940: during the first three months of service it was converted, a month of service equals eight weeks of benefit, and for the next months, starting from the fourth - four weeks of benefit. Due to the limit of 52 weeks of collecting benefits, it followed that the service of more than 10 months did not result in extension of the period of entitlement to benefits.

Payment of benefits could be withheld in a number of cases. These included: leaving a job without a valid reason, dismissal from work due to a serious misconduct, resignation from participation in training, cessation of work during a dispute between employer and employees, failure to take work commissioned by the local employment office (the conditions of the offer could not be worse than the average for the place of residence of the unemployed, one could not also be required to work in the plant during a strike or lock-out). The Bill also provided limited support for the selfemployed (this provision also included farmers). If the monthly business profits did not exceed $\$ 100$, it was possible to apply for a settlement, equal to the difference between the monthly profit and $\$ 100$. This aid could be used for up to 12 months. In the case of farmers, due to the nature of activities and profitability dependent on the seasons, profits were compared on an annual basis. The self-employed people in the agricultural sector or other, in the event of bankruptcy of the company were entitled to a «standard» \$20 unemployment benefit. As it turned out, the pool reserved for government grants for veterans was only $20 \%$ used. About half of those eligible applied for the benefit (even if in smaller amount) [4, p. 49]. In the end, only $14 \%$ of veterans took advantage of the full amount [10, p. 345].

The last area of assistance under the GI Bill was help in finding a job. For this purpose, the Veterans Placement Service Board was established, which was to cooperate with the United States Employment Service [18, p. 560]. Its importance - as in the case of unemployment benefits - was small. The American economy easily absorbed consecutive thousands of demobilized soldiers.

When adopting the GI Bill of Rights, it was expected that unemployment benefits would be the most important and consequential area of the Bill's impact. It was 
educational assistance that proved the biggest success. Postwar American society had undergone a major transformation and as a result of access to cheaper home loans and more democratic - i.e. available not only to the richest - access to education [1, p. 2]. Politically, the Bill strengthened Roosevelt's and later Truman's position, who easily showed how different were the new solutions from those adopted after WWI.

GI Bill of Rights played an important role in organizing US labour market. Some regulations had been passed even earlier. US had as many as 53 federal agencies that coordinated the wartime effort of the state. The primary role was played by War Production War (established in January 1942) chaired by Donald M. Nelson. All departments were subordinated to that office in terms of war production. The dynamics of wartime production growth was spectacular (150 \% between 1941-1942) $[11$, p. 203]. The rapid increase of production was possible due to major changes in labour relations. By far the most important was the declaration of biggest labour unions to hold all strikes and boycotts during the war. A few exceptions to the rule may be mentioned however. In 1943 United Mine Workers struck against too low salary. It is estimated that all labour activities between the end of 1941 and September 1945 took no more than 0,1 \% of total work time. Despite holding strike activities, labour unions were still very popular among workers. The number of union members increased by $50 \%$ between 1942 and 1945 [11, p. 204].

The employment relations were curbed by numerous institutions at the beginning of US engagement in war. For instance, by the National War Labour Board which was created in January 1942. The new office was eligible to determine the length of work time, earnings and the conditions for the functioning of labour unions. War Manpower Commission`s (which was founded three months later) main task was to allocate human resources in order to optimize the war production. These institutions along with the Office of Price Administration substituted for the market a politicized administrative regime supporting numerous union movement`s agenda: sick leaves, paid mealtimes, night-shift supplements.

As a result of huge demand for military devices, full employment existed for the very first time in the history of the US. At the same time, the state was truly an arsenal of democracy. The number of people employed in civil sectors also grew from 46.5 million in 1940 to 53 million in 1945 [11, p. 204]. A third of civil sectors workers were women. The total number of women employed rose by a third between 1941 and 1945. This growth was accompanied by the increase in working time - from 40 hours per week in 1941 to 45 hours per week in 1942 and 50 and 60 hours in the successive years. The earnings recorded a significant growth in manufacturing industry $-65 \%$ between 1941 and 1945. As a result of bigger demand for industrial products, as many as $17 \%$ people gave up their jobs in agriculture. It did not imply the decrease in the agricultural output. On the contrary, it rose by $22 \%$. Due to the growth of market prices, the income derived from the sale of these products increased twice during the war, while the famer's savings tripled. On the other hand, the real living costs rocketed by 28-34\% (according to different sources) between 1941-1945 with the most significant increase until 1943 and then only by $2 \%$ per year. It was a markedly lower growth as compared to that after World War I. 
After 1945, for the very first time since 1929, the US economy provided a stable and long lasting perspective for the employees. Additional relief was a result of savings from the time of the war. «Baby boom» and «generation of good times» was the legacy of those favorable circumstances. It all created additional demand for new products (cars, goods for children) which, in turn, boosted American economy. The result was contrary to prior and general expectations of American people who feared of the return unemployment. It particularly involved workers who were between jobs as war industries converted to peace and those who were returning to a 40-hour week and facing with a reduction in take-home pay.

Harry Truman had to challenge these anxieties in his first important speech after the surrender of Japan. In his «Special Message to the Congress Presenting a 21-Point Program for the Reconversion Period» (September 6, 1945) he sketched the frame of action for his tenure of office. The president announced rapid demobilization as well as to cancel and settle war contracts as quickly as possible (providing quick payment to contractors was underlined). It was all to permit contractors to proceed with peacetime production. In order to prevent inflation and undue hardship on consumers prices and rents were to be held until fair competition can operate. The labour unions were particularly interested in the restoring of prewar regulations. Truman promised to hold salary in line where their growth would cause inflationary price rises. On the other hand, where price ceilings would not be endangered, collective bargaining should be restored. The administration forecasted the deterioration of economic situation expecting «a great deal of inevitable unemployment». In this context Truman announced that «every eligible worker should be entitled to 26 weeks of unemployment benefits in any one year. The maximum weekly payment for those workers whose previous earnings were high enough, should be not less than $\$ 25$ per week» [17, p. 263]. As far as minimum wage is concerned, the president recommended that the Congress should increase the minimum its level to eliminate substandards of living. The ultimate goals to be achieved were full production and full employment (understood as a chance of getting a peacetime job for every worker who is ready, able, and willing to take one) at decent wages. It should all have been accompanied by the cooperation of labour and industry. Especially to keep strikes and lock-outs at a minimum. Truman expected that the management should not seize upon the chance to reduce wages and should give the opportunity to injure labour unions. On the other hand labour leaders should resist various temptations and limit widespread industrial strife. With this objective in view, the president proclaimed to convene a conference of representatives of organized labour and industry (pending the conference the no-strike, no-lock-out policy was expected to be continued).

The conference embarked on November, 5. The protection against group layoffs was the primary demand of the labour unions. They also favored keeping «closeshop» rule (only labour union members were eligible to be employed) and expected substantial pay-rises (30\% or more). Labour unions were getting more and more powerful not only because of the growing number of their members $(8.7$ million in 1940 and 14.3 million in 1945) but also because of the feeling of the safety as a natural power base of the democratic party. It all made Truman situation very difficult. 
He tried to soften up the union stance by taking the control over 26 petrochemical plants in October. The effect was quite the contrary. The conference failed in November, 30. The number of striking workers rose immediately: 0.5 million in December and as many as 2 million in February 1946. The most bothersome were miners and rail workers strikes which began in April and May 1946. The administration reaction was firm in May when military services started manning mines. The threat to repeat this action against rail strikers resulted with calling off the strike but with the administration concession to the union (the increase of hour wages by 18,5 cents per hour).

In general, there were nearly 5,000 strikes involving 4.6 million workers in $1946-$ which was the greatest amount of strike activity in the US. Their grounds were both economic and social. As price controls were lifted at the end of World War II, workers wanted to make up for wartime sacrifices. On the other hand management preferred to assert its right to manage [20, p. 525].

The way the administration cope with the strikes had significant influence both in social and political manner. The Truman`s robust attitude towards strikes was certainly favorable for his general popularity. On the other hand, it had substantially disaffected the labour unions. The wave of strikes seemed to have been temporarily broken and the anti-union legislation projects started to gain popularity in Congress and in state legislatures (the legislatures of 27 states passed the bills that limited the activities of labour unions). On the wave of anti-union sentiment a new project has been submitted by senator Robert Taft and Congressman Fred Hartley. The bill was designed to amend much of the National Labour Relations Act of 1935 (the Wagner Act). It provided liquidation of close-shop system and enabled the president to hold the strike in some sectors for 80 days. According to the project, all the financial reports of labour unions had to be made public while the financing the party committees was delegalized. The signum temporis of arising red scarce was the requirement to sign non-communist affidavits with the government by the labour union leaders. It was justified by the communist infiltration especially in the Congress of Industrial Organizations (CIO) that organized workers in industrial unions.

The important role in shaping Taft-Hartley Act was played by business leaders. After the war many companies sought to recapture lost power through aggressive collective bargaining and public relations drives. Exploiting public reactions to the postwar strike wave and capitalizing on the growing clamor of cold war anticommunism, they also launched a major campaign to revise the Wagner Act. Even though the new law was not all that many of them had hoped it would be, it nevertheless helped contain the power and scope of industrial unionism and signal the passing of an era in labor relations [5, p. 74].

The policy of moderate curbing of unions was supported by Truman. In January 1947 he said «We have got to have a certain restriction on the union element (...) because if we don't, we go haywire» [2, p. 302]. Thus he was surprised by the radicalism of the project submitted. The problem was that in 1946 Truman was dealing with short-term situations on his own presidential initiatives while in 1947 the question was whether to endorse long-term curbs imposed by a Republican Congress 
[8, p. 128]. The Cabinet was almost in favour of his acceptance the bill. More than 750,000 mails fostering Taft-Hartley Act were received by the White House. There was no certainty until the last moment about what the president was going to do. As much as from conviction and political calculation Truman vetoed the Taft-Hartley Act on June 20, 1947. Three days later the project became law by overcoming president's veto. The president voiced that the bill was too restrictive, ineffective, and contrary to the principles of US democracy. As Truman stated, the bill was «a shocking piece of legislation (...) bad for labour, bad for management and bad for the country». Disapproval of the bill earned him considerable credit with the unions. In the end antilabour sentiment in Congress prevailed. The only thing the unions could do were protests. CIO organized «operation Dixie» - a host of protests rallies against new law.

The protection of labour laws began by the numerous provisions of New Deal proved important legacy of Roosevelt era and the sign of progress of American society. Furthermore, the effective response of US administration to mine and railroad strikers in 1946 showed that existing prerogatives of the head of the state were sufficient to deal with «immature and irresponsible trade unions». The $80^{\text {th }}$ Congress supported strong anti-union laws pointing that power of labour union should be limited and subjected to external control. The main factors that influenced on the creation of conservative, anti-labour political climate were frequent strikes and annual pay boosts which industry used to raise prices. The new law forged the main contours of postwar labour relations and secured a critical venue of the new post-1945 order. As Nelson Lichtenstein put it: «The trade union found its efforts to bargain over the shape of political economy decisively blocked by a powerful remobilization of business and conservative forces» [9, p. 128-9]. Taft-Hartley did not destroy the union movement but imposed a legal straitjacket that curbed attempt to project a class-wide political strategy.

\section{Summary}

Both GI Bill of Rights and Taft-Hartley Act tackle the question of labour market. Both enactments had profound impact on postwar America. The GI Bill provided numerous and generous benefits for returning World War II veterans and successfully increased standard of living of American society. In short term, it helped to stabilize the job market: millions who would have flooded the job market instead opted for education and improved skills. The home loan program encouraged to move out of urban apartments and into own suburban homes and boosted American economy.

The GI Bill of Rights was thus as much an expression of gratitude and atonement for the soldiers fighting for American interests, but also - and perhaps primarily - an instrument of national economic policy. The increased earnings of better educated Americans have generated tax revenues eight to ten times greater than the total cost of the program. According to one of the congressional analysis «for every dollar the government invested in education under the GI bill, the nation received at least $\$ 5$ of benefits and as much as $\$ 12.50$ of benefits» [6, p. 8]. It is no surprise that it is called the best investment the U.S government has ever made.

Taft-Hartley Act (unlike GI Bill of Rights), one of most controversial law passed in US after 1945, was a response to the growth of the organized working class which put 
the American system of industrial relations at a crossroads. The tension arose when price controls were lifted and employees expected pay rises. The labour unions which were the natural representations of these claims organized 5.000 strikes in 1946, but also contributed to an anti-union climate in the US. The act passed over Truman's veto restricted union activities, allowed states to pass «right-to-work» laws, and spelled out «unfair labor practices» that were prohibited by the law. Its passing started a new era of relationship with labour unions.

\section{BIBLIOGRAPHY}

1. Bennett M., When Dreams Came True: The GI Bill and Making of Modern America, Brassey 2000.

2. Donovan R.J., Conflict and Crisis: The Presidency of Harry S. Truman, 1945-1948, London 1977.

3. Findings and Recommendations. Veterans' Benefits in the United States. A Report to the President by the President's Commission on Veteran`s Pensions, Washington 1956.

4. Greenberg M., The GI Bill of Rights [in] Historians on America. Decisions That Made a Difference, (ed. G. Clack), Dot1q Publishing, Washington 2010.

5. Griffith R., Forging America's postwar order: domestic politics and political economy in the age of Truman [in] The Truman Presidency (ed. M. J. Lacey), Cambridge 1989.

6. Hearings before the Subcommittee on Education and Health of the Joint Economic Committee Congress of the United States. One Hundredth Congress. Second Session. December 14 and 15, 1988, Washington 1989.

7. Humes E., Over Here. How the G. I. Bill Transformed the American Dream, Harcourt, New York 2006.

8. Jenkins R., Harry Truman. Pogromca komunizmu, Warszawa 1998.

9. Liechtenstein N., Labor in the Truman era: origins of the «private welfare state» [in] The Truman Presidency (ed. M. J. Lacey), Cambridge 1989.

10. Mettler S., The Creation of the G.I. Bill of Rights of 1944: Melding Social and Participatory Citizenship Ideals, "Journal of Policy History 2005, Vol. 17, No. 4.

11. Michałek K., Amerykańskie stulecie. Historia Stanów Zjednoczonych Ameryki 1900-2001, Warszawa 2004.

12. Milton J.W., For the Good of the Order: Nick Coleman and the High Tide of Liberal Politics in Minnesota, 1971-1981, Xlibris Corporation, Minnesota 2012.

13. Olson K. W., The GI Bill and Higher Education: Success and Surprise, «American Quarterly», 1973, Vol. 25, No. 5.

14. Patterson J., Great Expectations. The United States 1945-1974, Oxford University Press, Oxford 1996.

15. Polenberg R., One Nation Divisible: Class, Race, and Ethnicity in the United States Since 1938, Penguin Books, New York 1980.

16. Public Papers of the Presidents of the United States, vol. 12, 1943.

17. Public Papers of the Presidents of the United States, vol. 1, 1945.

18. United States Code, Vol. 2. Washington 2008.

19. United States Statutes at Large, United States Printing Office, Washington 1945.

20. Van Horn C. E., Schaffner, Work in America. An Encyclopedia of History, Policy and Society, vol. 1, Sanra Barbara 2003.

21. Young W. H., Young N. K., World War II and the Postwar Years in America, ABC-Clio, Santa Barbara 2010. 
Kamil Kowalski

ISSN 2078-4333. Вісник Львівського університету. Серія міжнародні відносини. 2016. Випуск 39

119

ВІД ЗАКОНУ ПРО ПРАВА ВІЙСЬКОВОСЛУЖБОВЦІВ 1944 РОКУ ДО ЗАКОНУ ПРО ВРЕГУЛЮВАННЯ ТРУДОВИХ ВІДНОСИН 1947 РОКУ: ВИБРАНІ ПРОБЛЕМИ ПОЛІТИКИ РИНКУ ПРАЦІ США

\author{
Каміль Ковальский \\ Лодзький університет, \\ вул. Революиії 1905, 41, м. Лодзь, Польща, 90-214, тел. +48 600105 729, \\ e-mail: kamil.kowalski@uni.lodz.pl
}

Однією з головних проблем США під час Другої Світової Війни було питання повернення економіки, налаштованої на військову продукцію, в мирне русло, що тісно пов'язано з демобілізацією 12 млн військовослужбовців. Термін обмеження кількості страйків, необхідний під час війни, припинявся. Саме ці два чинники - демобілізація та очікувана розбіжність між упрвлінням і профспілками - значною мірою впливали на американську політику на ринку праці.

Закон про права військовослужбовців 1944 р. (Джі Ай Біл) був комплексною програмою полегшення повернення ветеранів до цивільного життя. Головна частина закону концентрувалася на правилах підтримки колишніх солдат. Закон про врегулювання трудових відносин 1947 р. (Закон Тафта-Хартлі) республіканська ініціатива, мотивована серією великих страйків, страхом перед комуністичною інфільтрацією профспілок, а також значним збільшенням сили та чисельності профспілок. Ці обставини створили в післявоєнних США атмосферу, неприйнятну для профспілок. Закон, зрештою, затвердили, проте після подолання вето президента Трумена, що виявилося спритним політичним заходом.

Ключові слова: праця; перестановка продукції; післявоєнна економіка; Трумен. 